\title{
An overview of E-waste, its management practices and legislations in present Indian context
}

\author{
Rajeev Rajput* \\ Department of Applied Sciences and Humanities (Division-Environmental Sciences), ABES \\ Institute of Technology, Ghaziabad-201009 (Uttar Pradesh), India \\ Rinki \\ Department of Information Technology, Netaji Subhas University of Technology, Sector-3, \\ Dwarka, New Delhi-110078, India \\ Nidhi Ahuja Nigam \\ Department of Applied Sciences and Humanities (Division-Environmental Sciences), \\ Inderprastha Engineering College, Ghaziabad-201010 (Uttar Pradesh), India \\ ${ }^{*}$ Corresponding Author. Email: drrajeevrajput@gmail.com
}

\section{How to Cite}

Rajput, R. et al. (2021). An overview of E-waste, its management practices and legislations in present Indian context. Journal of Applied and Natural Science, 13(1), 34 - 41. https://doi.org/10.31018/jans.v13i1.2440

\begin{abstract}
E-waste coming out from the electronic sector of the entire world is harming the world's environment. There has been a pattern of a substantial increase in the production of E-waste worldwide. This is as a consequence of population increase, industrialization, urbanization and economic activity. Since the last decade, the rate of consumerism has been found to be very high due to higher economic growth, which has resulted in increased E-waste production. Almost all countries are recycling more and more E-waste, but a million tonnes of E-waste still coming out. Experts believe that the rise of E-waste is due to our rapidly changing lifestyles. We have started adopting new electronic devices coming into the market, trying to make life more convenient. In India, electronic waste is growing at $10 \%$ per annum. The trend of urbanization has played a significant role in the enhancement of E-waste generation. The population living in urban areas was $27.67 \%$ in $2000,38.03 \%$ in 2018 , and is expected to reach approximately $42 \%$ in 2025 . As the population increases, the amount of E-waste will also rise to an alarming situation. This review paper provides the present scenario of E-waste and its management practices and legislation in the present Indian context. This would help all the stakeholders involved in the production of electrical equipment to gain better understanding of E-waste.
\end{abstract}

Keywords: Environmental pollution, E-waste, Human health, Legislation, Management

\section{INTRODUCTION}

E-waste is described as discarded electrical and electronic devices or parts . E-waste or Waste electrical and electronic equipment (WEEE) is the term used to describe old, end of life (Perkins et al., 2014) or discarded appliances using electricity. E-waste includes computers, consumer electronics, fridges etc. which are disposed-off by their original users. According to E-waste Rules (2016), E-waste means Electrical and electronic equipment (EEE), whole or in part discarded as waste by the buyer as well as rejects from manufacturing, refurbishment and repair processes (www.cpcb.nic.in).
Categories of E-waste (E-waste categories pursuant to the European Union-EU Directive 2002/96/EC)

1. Large household appliances (refrigerators/freezers, washing machines, dishwashers).

2. Small household appliances (toasters, coffee makers, irons, hairdryers).

3. Information technology (IT) and telecommunications equipment (personal computers, telephones, mobile phones, laptops, printers, scanners, photocopiers).

4. Consumer equipment (televisions, stereo equipment, electric toothbrushes).

5. Lighting equipment (fluorescent lamps).

6. Electrical and electronic tools (handheld drills, saws, screwdrivers). 
7. Toys, leisure and sports equipment.

8. Medical equipment systems (with the exception of all implanted and infected products).

9. Monitoring and control instruments.

10.Automatic dispensers.

The rapid growth of technology, up-grading technical innovations, and a high rate of obsolescence in the electronics industry have led to an increase in E-waste volume. Studies by Bertram et al. (2002); and Cui and Zhang (2008) also affirm that wastes from electrical and electronic equipment are the fastest growing waste category. United Nation University (UNU) report showed that 44.7 million metric tonnes (Mt) E-waste was generated worldwide in 2016 and predicted that E-waste's total quantity to be increased up to 52.2 Mt by 2021 . Out of the total E-waste generated, only $20 \%$ E-waste was officially collected and recycled formally (Baldé et al., 2017). According to Forti et al., (2020), the global Ewaste generation in 2019 was 53.6 million metric tons (Mt), of which only $17.4 \%$ was officially recorded as being properly collected and recycled. It has risen with 1.8 Mt since 2014, but the overall production of E-waste has increased by $9.2 \mathrm{Mt}$. This suggests that recycling efforts are not keeping track with E-waste's global growth. It is further estimated that the amount of Ewaste generated will exceed $74 \mathrm{Mt}$ in 2030. In India, a total of 3230 metric kiloton (kt) of E-waste was generated in 2019, which comes to $2.4 \mathrm{~kg}$ per capita of Ewaste.

Globally $15-20 \%$ of E-waste is recycled while the remainder is dumped into developing countries. E-waste from developed countries finds an easy way into developing countries within the name of trade which is further complicating the issues associated with waste management. Despite the existence of varied conventions, there is still a comparatively high flow (50-80 per cent) of WEEE from the USA, Canada, Europe, Japan, and Korea to developing countries like India, China, Taiwan, Pakistan, Bangladesh, Srilanka, Bhutan, Nepal and various African countries (Puckett et al., 2002; Terazono, 2006; Cobbing, 2008; Johri, 2008; Shamim et al., 2015). Some developing countries are becoming the fastest-growing markets for EEE and produce a significant WEEE volume (Widmer et al., 2005). In India few cities namely, Mumbai, Delhi, Madras, Hyderabad and Ahmedabad are notable regions, which receive a majority of E-waste as a charity (Imran et al., 2017; Arya et al., 2020). The European Union (EU) directive, the Basel Convention, the take-back scheme, the Extended Producer Responsibility (EPR), the Organization for Economic Co-operation and Development (OCED) became more common among the popular legislation. These guidelines and amendments aim to deal with massive volumes of E-waste in a proactive and environmentally sustainable manner, without altering the ecological parity (Gollakota et al., 2020). Solid waste man- agement, which is already an enormous problem in India, has become more complicated due to E-waste. India receives the partially obsolete and scrap gadgets (Borthakur and Govind, 2017; Ashfaq and Khatoon 2014) from western countries due to the weak legislations over its handling and management (Agoramoorthy and Chakraborthy, 2012). Clear government policies and competent bureaucracies for solid waste management are urgently required, particularly in those countries where population growth in semi-urban areas is rapid by urbanization. Services and programs to provide adequate disposal of waste for the management of toxic biological and chemical wastes, minimization and recycling will be required (Rajput et al., 2009).

\section{ENVIRONMENT AND HEALTH CONCERN}

E-waste is considered as being highly contagious for the environment and its components (Rakib and Ali, 2014). The processing technologies such as smelting, cutting, crushing, incineration, and combustion release toxic emissions (Lee et al., 2007). Traditional E-waste processing through inappropriate networks in India has resulted in an immense quantity of heavy metals and other contaminants into the natural environment, which negatively affects natural environments such as soil, water, dust and plants (Awasthi et al., 2016). The main environmental concerns are resource depletion due to the manufacturing of new electrical and electronic equipment and dangerous substances arising from waste. If electrical and electronic products are disposed -off in landfill sites, a million tonnes of materials that might be recovered and reused for new products are being lost. E-waste varies chemically and physically from municipal or industrial waste. E-waste is much more life-threatening than many other municipal wastes because electronic devices contain thousands of components manufactured from lethal chemicals and metals such as lead, cadmium, polyvinyl chlorides (PVCs), brominated flame retardants, beryllium, antimony, phthalates, chromium and mercury (Saoji, 2012). These wastes may have adverse effects on the environment and human health (Gaidajis et al., 2010; Alabi et al., 2020). Although these dangerous substances are usually only contained in small amounts, they cause serious environmental damage. Improper handling of $\mathrm{E}$ -waste adds hazardous material to environmental cycles through particulate matter from dismantling activities, fly and bottom ash from burning activities, leachates from dumping sites and wastewater from dismantling and shredding facilities. Emissions due to burning of E-waste can give rise to greenhouse gases contributing to global warming. The human health impacts of E-waste recycling have been well studied by researchers around the world, especially in those countries where E-waste recycling is carried out by the informal 
sector (Herat, 2020). Reproductive and endocrine systems, kidney, bones and the nervous systems etc. may be damaged by long-term exposure to E-waste content (Islam et al., 2019). Once these harmful chemicals are released into the human body, they can be accumulated in the fatty tissues and affect the human population residing around the informal E-waste markets (Zeng et al., 2017; Zhang et al., 2017; Liu et al., 2018).

Several elements present in E-waste pose health hazards on human beings. The important ones are that chronic exposure to arsenic can lead to various skin diseases, decrease nerve conduction velocity, and cause lung cancer. Beryllium causes Chronic Beryllium Disease (beryllicosis), which primarily affects the lungs. Long-term exposure of cadmium causes Itai-itai disease. Lead is a neurotoxin that affects the kidneys and the reproductive system. Mercury affects the cardiovascular and central nervous system. Brominated Flame Retardant (BFR) can lead to severe hormonal disorders. The various health effects on human beings by different hazardous materials present in the E-waste are indicated in Table 1 (Adapted from Frazzoli et al., 2010; Kumar and Singh, 2014; Li and Achal, 2020).

\section{TREATMENT OF E-WASTE}

E-waste is a mixture of valuable material that is recoverable and recyclable with toxic substances that must be safely disposed of as its treatment is complicated. E -waste requires both labour-intensive technical processes for the separation of toxic waste. Handling of Ewaste by beginning with manual dismantling has been recommended as the best starting process for its treatment. Recovery of the precious material is still not worth because of the heterogeneity of the material. Heterogeneity is causing a big problem in terms of proper recovery. The metal content is around $28-30 \%$ in which Copper is 10 to $20 \%$; Lead is 1 to $5 \%$; Nickel is 1 to $3 \%$ and precious metals like silver, platinum, and gold are 0.3 to $0.4 \%$. Other materials are plastics $(19 \%)$, bromine $(4 \%)$, glass and ceramics $(49 \%)$. In addition to these inorganic elements, other essential organic compounds are also present in circuit boards such as isocyanate phosgene acrylic and phenolic resins (Ludwig et al., 2003). The dismantled E-waste is separated into glass, copper, steel, aluminium, plastic, printed circuit boards etc. E-waste's overall PCB content is $3-5 \%$ by weight of E-waste, which requires environmentally safe recycling methods. The remaining 95$97 \%$ of metals, plastics, and glass can easily be dissembled separated manually without harming the environment (Chatterjee, 2012). The hazardous components like capacitors, CRT screens, CFC gases, light bulbs and batteries are also separated and removed at this stage. Mechanical processing which is typically a large-scale operation allows the increase in recyclable materials in a dedicated fraction and further isolates hazardous materials. Typical components of automated processing plants are the Crushing units, Shredders, Magnetic separators and Air separators.

Most of the fractions obtained here are refined to be sold as secondary raw materials. At the completion of refining and after extraction of valuable fractions, the contaminants which are typically unusable and toxic are disposed-off in specially built hazardous waste disposal facilities.

\section{E-WASTE MANAGEMENT IN INDIA}

The E-waste stream within the country is rising three times faster than the municipal waste stream. According to Global E-waste Monitor 2020, India is the thirdlargest electronic waste producer in the world after China and the USA. These three countries generate approximately $38 \%$ of the total of 53.6 million tonnes (Mt) of E-waste (Times of India, July 4 2020). E-waste management in India has been largely based on the highly organized informal sector, including the collection, segregation, dismantling and recycling. The informal sector's recycling is done in a primitive way by using inefficient methods which cause damage to the health of the workers and environmental damage and loss of valuable materials. E-waste management in India differs from that in the world. E-waste disposal procedures are a significant concern as a result of informal recycling activities. The quantification of E-waste in India is thus challenging and there is no method for regulating the movement of E-waste in the system (Sankhla et al., 2016).

According to a study on Electricals and Electronics Manufacturing in India, conducted by the Associated Chambers of Commerce and Industry of India (ASSOCHAM-NEC) in 2018, Maharashtra produced $19.8 \%$ of E-waste but recycled only about 47,810 tonnes per annum (TPA), Tamil Nadu (13\%) recycled about 52,427 TPA, Uttar Pradesh (10.1\%) recycled about 86,130 TPA. West Bengal contributed 9.8\%, Delhi $9.5 \%$, Karnataka $8.9 \%$, Gujarat $8.8 \%$, and Madhya Pradesh $7.6 \%$ of E-waste. Among the top ten E-waste generating cities, Mumbai ranked first followed by Delhi, Bangalore, Chennai, Kolkata, Ahmadabad, Hyderabad, Pune, Surat and Nagpur. Chandigarh generates $17 \mathrm{~kg}$ of E-waste annually, resulting in 4100 tonnes of E-waste from Chandigarh's households (Ravindra and Mor, 2019). There is no large-scale organized E-waste recycling facility in India and the entire recycling exists in the unorganized sector (https://cpcbbrms.nic.in). Most of the activities, like collection, transportation, segregation, dismantling, recycling, disposal, etc., are carried out by the informal sector. The E-waste is mostly picked up by the rag pickers who pay a certain amount to the customer from whom the waste is col- 
Table 1. Various health effects by different hazardous material present in the E-waste (Adapted from Frazzoli et al., 2010; Kumar and Singh, 2014; Li and Achal, 2020).

\begin{tabular}{|c|c|c|c|}
\hline S.No. & Pollutant & Source of E-waste & Health effects \\
\hline 1 & Arsenic & $\begin{array}{l}\text { Semiconductors, microwaves, LEDs } \\
\text { (Light-emitting diodes), solar cells }\end{array}$ & $\begin{array}{l}\text { Chronic exposure to arsenic can lead to various dis- } \\
\text { eases of the skin, decrease nerve conduction velocity } \\
\text { and cause lung cancer. }\end{array}$ \\
\hline 2 & Barium & $\begin{array}{l}\text { Electron tubes, filler for plastic and } \\
\text { rubber, lubricant additives }\end{array}$ & $\begin{array}{l}\text { Cause brain swelling, muscle weakness, damage to } \\
\text { the heart, liver and spleen. }\end{array}$ \\
\hline 3 & Beryllium & $\begin{array}{l}\text { Switchboards and printed circuit } \\
\text { board }\end{array}$ & $\begin{array}{l}\text { Carcinogenic; Chronic Beryllium Disease } \\
\text { (Beryllicosis), a disease which primarily affects the } \\
\text { lungs. }\end{array}$ \\
\hline 4 & $\begin{array}{l}\text { Brominated } \\
\text { Flame } \\
\text { Retardant }\end{array}$ & $\begin{array}{l}\text { Casing, circuit boards (plastic), PVC } \\
\text { cables }\end{array}$ & $\begin{array}{l}\text { Combustion of halogenated case material and printed } \\
\text { wiring boards at lower temperatures releases toxic } \\
\text { emissions, including dioxins, leading to severe hormo- } \\
\text { nal disorders. }\end{array}$ \\
\hline 5 & Cadmium & $\begin{array}{l}\text { Batteries, solder, alloys, circuit } \\
\text { boards, computer batteries, cathode } \\
\text { ray tubes (CRTs) }\end{array}$ & $\begin{array}{l}\text { Carcinogen; Long-term exposure causes Itai-itai dis- } \\
\text { ease, which causes severe pain in the joints and } \\
\text { spine. It affects the kidneys and softens bones. }\end{array}$ \\
\hline 6 & Chrome & Dyes, switches, solar & $\begin{array}{l}\text { Inhaling hexavalent chromium can damage liver and } \\
\text { kidneys and cause bronchial maladies, including asth- } \\
\text { matic bronchitis and lung cancer. }\end{array}$ \\
\hline 7 & Cobalt & Insulators & $\begin{array}{l}\text { Accumulate to toxic levels in the liver, kidney, pancre- } \\
\text { as, heart, and skeleton and skeletal muscle. Cobalt } \\
\text { has been found to be human carcinogen. }\end{array}$ \\
\hline 8 & Copper & $\begin{array}{l}\text { Conducted in cables, copper rib- } \\
\text { bons, coils. }\end{array}$ & $\begin{array}{l}\text { Nausea, Vomiting, Diarrhoea, Liver Damage, Kidney } \\
\text { Damage, Death. }\end{array}$ \\
\hline 9 & Lead & $\begin{array}{l}\text { Lead rechargeable batteries, tran- } \\
\text { sistors, lithium batteries, PVC } \\
\text { (polyvinyl chloride), stabilizers, la- } \\
\text { sers, thermoelectric elements, cir- } \\
\text { cuit boards. }\end{array}$ & $\begin{array}{l}\text { A neurotoxin that affects the kidneys and the repro- } \\
\text { ductive system. High quantities can be fatal. It affects } \\
\text { mental development in children. }\end{array}$ \\
\hline 10 & Lithium & $\begin{array}{l}\text { Mobile telephones, photographic } \\
\text { equipment, video equipment } \\
\text { (batteries). }\end{array}$ & $\begin{array}{l}\text { Corrosive to the eyes, the skin and the respiratory } \\
\text { tract. Corrosive on ingestion. Inhalation of the sub- } \\
\text { stance may cause lung oedema. }\end{array}$ \\
\hline 11 & Mercury & $\begin{array}{l}\text { Components in copper machines } \\
\text { and steam irons; batteries in clocks } \\
\text { and pocket calculators, switches, } \\
\text { LCDs. }\end{array}$ & $\begin{array}{l}\text { Affects the cardiovascular system, central nervous } \\
\text { system, kidneys and immune system. }\end{array}$ \\
\hline 12 & Nickel & $\begin{array}{l}\text { Alloys, batteries, relays, semicon- } \\
\text { ductors, pigments. }\end{array}$ & $\begin{array}{l}\text { Carcinogenic; Lung cancer, nose cancer, larynx can- } \\
\text { cer and prostate cancer, Asthma and chronic bronchi- } \\
\text { tis. }\end{array}$ \\
\hline 13 & $\begin{array}{l}\text { PCBs } \\
\text { (polychlorina } \\
\text { ted } \\
\text { biphenyls) }\end{array}$ & $\begin{array}{l}\text { Transformers, capacitors, softening } \\
\text { agents for paint, glue, plastic. }\end{array}$ & $\begin{array}{l}\text { PCBs have been shown to cause a number of serious } \\
\text { non-cancer health effects, including effects on the } \\
\text { immune system, reproductive system, nervous sys- } \\
\text { tem, endocrine system and other health effects. }\end{array}$ \\
\hline 14 & Selenium & $\begin{array}{l}\text { Photoelectric cells, pigments, photo- } \\
\text { copiers, fax machines. }\end{array}$ & $\begin{array}{l}\text { Cause selenosis. The major symptoms are hair loss, } \\
\text { nail brittleness, and neurological abnormalities. }\end{array}$ \\
\hline 15 & Silver & $\begin{array}{l}\text { Capacitors, switches (contacts), } \\
\text { batteries, resistors. }\end{array}$ & $\begin{array}{l}\text { Cardiac abnormalities, permanent brain and nervous } \\
\text { system damage. }\end{array}$ \\
\hline 16 & Zinc & $\begin{array}{l}\text { Steel, brass, alloys, disposable and } \\
\text { rechargeable batteries, luminous } \\
\text { substances. }\end{array}$ & $\begin{array}{l}\text { Cause health problems like stomach cramps, skin } \\
\text { irritations, vomiting, nausea and anaemia. }\end{array}$ \\
\hline 17 & Toner Dust & $\begin{array}{l}\text { Toner cartridges for laser printers/ } \\
\text { copiers. }\end{array}$ & $\begin{array}{l}\text { An irritant to people with respiratory conditions such } \\
\text { as asthma or bronchitis. }\end{array}$ \\
\hline 18 & Americium & $\begin{array}{l}\text { Medical equipment, fire detectors, } \\
\text { active sensing element in smoke } \\
\text { detectors. }\end{array}$ & Radioactivity. \\
\hline
\end{tabular}


lected. Rag pickers accumulate all categories of waste such as paper, books, newspapers, plastic, cardboard, polythene, metals, etc. including E-waste, and earn their livelihood by selling it to mediators or scrap dealers. This is a significant income source not only for rag pickers but also for mediators and scrap dealers. Ewaste is typically handled by unskilled staff and they do not take sufficient safety precautions to reduce the cost (Purushothaman et al., 2020). Recycling and disposal techniques are not used properly due to lack of adequate technology. Very few companies have voluntarily adopted the 'take-back' system. There is no clear data on the quantity generated (Arya et al., 2020) and disposed-off per annum and the resulting extent of environmental risk. According to the literature analysis, only $50 \%$ of the public are aware of the electronic goods' environmental and health impacts, so there is an immediate need to introduce a proper E-waste management system in India (Khurrum et al., 2011). Shirodkar and Terkar (2017) highlight the condition and consequences of E-waste management in India and propose a new, specific management model as the best approach for $\mathrm{E}$ -waste management in India.

\section{E-waste regulation in India}

There are various laws that directly or indirectly affect hazardous wastes and toxic substances. Environmental (Protection) Act, 1986 deals comprehensively with environmental issues. Section 6 explicitly authorized the Central Government to lay down rules on different matters including -

1) Protocols and precautions for the processing of hazardous substances.

2) Prohibition and limitation on the handling of hazardous substances.

In view of E-waste's growing problems, the Central Government has notified these rules in the exercise of the powers provided under Sections 6,8 and 25 of the Environmental (Protection) Act, 1986. E-waste (Management) Rules, 2016 supersedes the E-waste (Management and Handling) Rules, 2011. It consists of 24 rules split into 6 Chapters and 4 Schedules. This regulation aims to encourage recycling of usable E-waste products, thus minimizing hazardous wastes destined for landfill and ensuring that all forms of E-waste are handled in an environmentally sound manner. These rules shall come into force from October 12016.

E-waste (Management) Rules 2016 recognizes and defines each of the stakeholders (producer, manufacturer, consumer, bulk consumer, collection centers, dealers, e-retailers, refurbishers, dismantlers, and recyclers), who are involved with the production of electric equipment and management of the waste generated at the end of its useful life. The responsibilities of each stakeholder are also explicit in the rule. E-waste management is based on the concept of Extended Producer responsibility (EPR). It is considered an environmental protection policy that makes the producer of the product responsible for the entire life cycle of the product and particularly for the take-back, recycling, and final disposal of the product. One of E-waste management's important aspects is the designation and application of EPR (Corsini et al., 2015). Many researchers have investigated various aspects of E-waste management based on EPR. The EPR is considered internationally as one of the most successful ways to resolve the problem of E-waste. However, unlike in the developed world, the introduction of EPR in developing countries is a significant concern for policymakers due to the informal sector's active participation (Pariatamby and Victor, 2013). EPR is a regulatory strategy that allows manufacturers to finance the costs of collecting, recycling, and/or safely disposing of products consumers no longer want (Nash and Bosso, 2013). Favot et al., (2016) analyze the Italian collective system for the management of household Waste Electrical and Electronic Equipment (WEEE), and its evolution over time, following the European Directives on WEEE, which include the EPR. The EPR and Producer Responsibility Organization (PRO) programs have been presented in an articulated manner in European countries and in India, we are yet to explore its full potential (Garlapati, 2016).

Specific targets have been set up for the producers to manage $30 \%$ of the waste generated during the first two years of implementation of the rule. This target has been gradually increased so that by the seventh year of implementation of this rule, nearly $70 \%$ of the Ewaste generated is properly managed. The penalty of non-compliance of meeting the target includes cancellation of EPR authorization which would result in the producer not being able to put products in the market until EPR authorization is re-granted. Apart from having a planned system for managing E-waste, the producers are required to reduce the number of hazardous substances in their equipment. The equipment should not contain lead, mercury, hexavalent chromium, polybrominated biphenyls and polybrominated diphenyl ethers beyond a maximum concentration value of $0.1 \%$ cadmium of $0.01 \%$ by weight in homogenous materials.

\section{Amendments in E-waste Management Rules 2018}

The E-waste Management Rules 2016 is amended vide notification G.S.R. 261(E), dated March 22, 2018. The amendment in rules was carried out to channel the E-waste produced within the country to authorized dismantlers and recyclers to formalize the E-waste recycling market. The collection targets under the supply of Extended Producer Responsibility (EPR) within the Rules are updated and targets are set for new producers who have recently begun their sales operations. 
Rajput, R. et al. / J. Appl. \& Nat. Sci. 13(1): 34 - 41 (2021)

Key facets of the E-waste (Management) Amendment Rules, 2018 are as follows:

1. The E-waste collection targets under EPR are revised and can be applicable from October 12017 . The phase-wise collection targets for E-waste in weight shall be $10 \%$ of the waste generation quantity as set out in the EPR Plan during 2017-18, with a yearly increase of $10 \%$ by 2023 . After 2023 onwards, the target will be set at $70 \%$ of the volume of waste generation as stated in the EPR Plan.

2. The quantity of E-waste collected by producers from the October 12016 to September 302017 shall be taken into account for the updated EPR targets until March 2018.

3. Separate E-waste collection targets are set for the new producers, i.e., those producers whose number of years of sales operation is smaller than their products' average lives. Standard lives of the things must be in accordance with the guidelines provided by CPCB, 2016 (Central Pollution Control Board, India) from time to time.

4. Producer Responsibility Organizations (PROs) shall apply to the CPCB for registration to carry out the activities stated in the regulations.

5. According to the Reduction of Hazardous Substances (RoHS) provisions, the cost for sampling and testing shall be borne by the Government to execute the RoHS test. If the test results do not validate the specification of RoHS, the manufacturer shall bear the cost of the test.

\section{Conclusion}

E-waste not only contains hazardous material but also at the same time has precious material. There is a lot of concern about E-waste from the government side, but people should also be concerned because it has a variety of hazardous materials. In India reuse, remanufacturing and recycling of E-waste are done by mostly informal recycling, i.e., not authorized by the Government. Some of the E-waste amount is recycled in the informal sector, but most of the E-waste is being dumped in a landfill after recovery of the valuable material. It triggers different forms of health and environmental hazards. Therefore, it is important to overcome the gap between the formal and informal E-waste sectors to fully exploit E-waste's resource value and develop a sustainable management pattern. Formalizing the informal sector through a consistent recycling scheme is critical and strongly advised. Proper E-waste management will enable effective procurement and collection right up to extraction and disposal of material, ensuring that this large E-waste volume will turn into lucrative goods. Efficient recycling, E-waste disposal, and stringent enforcement of E-waste Management regulations are required to mitigate the adverse effects of E-waste on the environment and human health that will ensure India's waste management viability system.

\section{ACKNOWLEDGEMENTS}

The authors are thankful to the Director, ABES Institute of Technology, Ghaziabad and the Director, Inderprastha Engineering College, Ghaziabad for their motivation and encouragement for writing this article.

\section{Conflict of Interest}

The authors declare that they have no conflict of interest.

\section{REFERENCES}

1. Agoramoorthy, G. \& Chakraborty, C. (2012). Control electronic waste in India. Nature, 485, 309. https:// doi.org/10.1038/485309b.

2. Alabi, O. A., Adeoluwa, Y. M. \& Bakare, A. A. (2020). Elevated Serum $\mathrm{Pb}, \mathrm{Ni}, \mathrm{Cd}$, and $\mathrm{Cr}$ Levels and DNA Damage in Exfoliate d Buccal Cells of Teenage Scavengers at a Major Electronic Waste Dumpsite in Lagos, Nigeria. Biological Trace Element Research, 194 (1), 24-33. https:// doi.org/10.1007/s12011-019-01745-z

3. Arya, S., \& Kumar, S. (2020). E-waste in India at a Glance: Current Trends, Regulations, Challenges and Management Strategies. Journal of Cleaner Production, 122707. https://doi.org/10.1016/j.jclepro.2020.122707

4. Ashfaq, A., \& Khatoon, A. (2014). Environmental impacts assessment of electronic waste 1011 management. International Journal of Current Microbiology and Applied Sciences, 3, 772-779.

5. Awasthi, A.K., Zeng, X. \& Li, J. (2016). Environmental pollution of electronic waste recycling in India: A critical review. Environmental Pollution, 211, 259-270. https:// doi.org/10.1016/j.envpol.2015.11.027

6. Baldé, C.P., Forti, V., Gray, V., Kuehr, R. \& Stegmann, P. (2017). The Global E-waste Monitor: Quantities, Flows and Resources (Bonn/Geneva/Vienna). United Nations University (UNU), International Telecommunication Union (ITU) \& International Solid Waste Association (ISWA). Bonn/Geneva/Vienna. https://collections.unu.edu/view/ UNU: 6341.

7. Bertram, M., Graedel, T.E., Rechberger, H. \& Spatari, S. (2002). The Contemporary European copper cycle: waste management subsystem. Ecological Economics, 42(1-2), 43-57. https://doi.org/10.1016/S0921-8009(02)00100-3

8. Borthakur, A., \& Govind, A. (2017). How well are we managing E-waste in India: evidences from the city of Bangalore. Energy, Ecology and Environment, 2(4), 225-235. https://doi.org/10.1007/s40974-017-0060-0

9. Chatterjee, S. (2012). Sustainable electronic waste management and recycling process. American Journal of Environmental Engineering, 2(2), 23-33. https:// doi.org/10.5923/j.ajee.20120201.05

10. CPCB. (2016). E-waste Management. Gazette of India, Extraordinary Part II, Section-3, Sub-Section-i, Government of India, Ministry of Environment, Forests and Climate Change, New Delhi. 
11. Cobbing, M. (2008). Toxic Tech: Not in Our Backyard: Uncovering the Hidden Flows of E-waste. Greenpeace International, Amsterdam, The Netherlands.

12. Corsini, F., Rizzi, F., Gusmerotti, N.M. \& Frey, M. (2015). Extended producer responsibility and the evolution of sustainable specializations: evidences from the E-waste sector. Bussiness Strategy and the Environment, 24: 466476. https://doi.org/10.1002/bse.1831

13. Cui, J. \& Zhang, L. (2008). Metallurgical recovery of metals from electronic waste: A review, Journal of Hazardous Material, 158(2-3), 228-256. https://doi.org/10.1016/ j.jhazmat.2008.02.001

14. Favot, M., Veit, R. \& Massarutto, A. (2016). The evolution of the Italian EPR system for the management of household Waste Electrical and Electronic Equipment (WEEE)Technical and economic performance in the spotlight. Waste Management, 56, 431-437. https://doi.org/10.1016/ j.wasman.2016.06.005

15. Forti, V., Balde, C.P., Kuehr, R. \& Bel, G. (2020). The Global E-Waste Monitor, Quantities, flows and the circular economy potential. United Nations University (UNU)/ United Nations Institute for Training and Research (UNITAR) - co-hosted SCYCLE Programme, International Telecommunication Union (ITU) \& International Solid Waste Association (ISWA), Bonn/Geneva/Rotterdam.

16. Frazzoli, C., Orisakwe, O.E., Dragone, R. \& Mantovani, A. (2010). Diagnostic health risk assessment of electronic waste on the general population in developing countries' scenarios. Environment Impact Assessment Review, 30 (6),388-399. https://doi.org/10.1016/j.eiar.2009.12.004

17. Garlapati, V.K. (2016). E-waste in India and developed countries: Management, recycling, business and biotechnological initiatives. Renewable and Sustainable Energy Review, 54, 874-881. https://doi.org/10.1016/j.rser.20 15.10.106

18. Gaidajis, G., Angelakoglou, K. \& Aktsoglou, D. (2010). Ewaste: Environmental problems and current management. Journal of Engineering Science and Technology Review, 3(1): 193-199. https://doi.org/10.25103/jestr.031.32

19. Gollakota, A.R.K., Gautam, S. \& Shu, C.M. (2020). Inconsistencies of E-waste management in developing nations - Facts and plausible solutions. Journal of Environmental Management, 261, 110234. https://10.10 16/j.jenvman.2020.110234

20. Herat, S. (2020). Achieving sustainability in solving the electronic waste (e-waste) problem. Environment Conservation Journal, 21(3, 7-15. https://doi.org/10.36953/ ECJ.2020.21302

21. Imran, M., Haydar, S., Kim, J., Awan, M. R., \& Bhatti, A. A. (2017). E-waste flows, resource recovery and improvement of legal framework in Pakistan. Resources, Conservation and Recycling, 125: 131-138. https:// doi.org/10.1016/j.resconrec.2017.06.015.

22. Islam, A., Ahmed, T., Awual, M. R., Rahman, A., Sultana, M., Aziz, A. A., Monir, M.U., Teo, S.H. \& Hasan, M. (2019). Advances in sustainable approaches to recover metals from e-waste-A review. Journal of Cleaner Production, 224, 118815. https://doi.org/10.1016/j.jclepro.20 19.118815

23. Johri, R. (2008). E-waste Implications, regulations and management in India and current global best practices. TERI, New Delhi.
24. Khurrum, M., Bhutta, S., Omar, A. \& Yang, X. (2011). Electronic Waste: A Growing Concern in Today's Environment. Hindawi Publishing Corporation, Economics Research International, 2011, 1-8. https://doi.org/1 0.11 $55 / 2011 / 474230$

25. Kumar, U. \& Singh, D. (2014). Electronic waste: concerns \& hazardous threats. International Journal of Current Engineering and Technology, 4, 802-811

26. Lee, J. C., Song, H.T. \& Yoo, J.M. (2007). Present status of the recycling of waste electrical and electronic equipment in Korea. Resources Conservation and Recycling, 50(4, 380-397. https://doi.org/10.1016/j.resconrec.2007.0 1.010

27. Li, W., \& Achal, V. (2020). Environmental and health impacts due to e-waste disposal in China - A review. Science of the Total Environment, 139745. https:// doi.org/10.1016/j.scitotenv.2020.139745

28. Liu, Y., Huo, X., Xu, L., Wei, X., Wu, W., Wu, X., \& Xu, X. (2018). Hearing loss in children with ewaste lead and cadmium exposure. Science of the Total Environment, 624, 621-627. https://doi.org/ 10.1016/j.scitotenv.2017.12.091.

29. Ludwig, C., Hellweg, S. \& Stucki, S. (2003). In Municipal solid waste management; Strategies and Technologies for sustainable solutions. Spinger, Berlin, pp 320-322.

30. Nash, J. \& Bosso, C. (2013). Extended producer responsibility in the United States: full speed ahead? Journal of Industrial Ecology, 17, 175-185. https://doi.org/10.1111/ j.1530-9290.2012.00572.x

31. Pariatamby, A. \& Victor, D. (2013). Policy trends of Ewaste management in Asia, Journal of Material Cycles and Waste Management, 15, 411-419. https:// doi.org/10.1007/s10163-013-0136-7

32. Perkins, D.N., Drisse, M.M., Nxele, T. \& Sly, P.D. (2014). E-waste: A Global Hazard. Annals of Global Health, 80(4): 286-295. https://doi.org/10.1016/j.aogh.2 014.10 .001

33. Puckett, J., Byster, L. \& Westervelt, S. (2002). Exporting Harm: The High-Tech Trashing of Asia. The Basel Action Network (BAN) and Silicon Valley Toxics Coalition (SVTC), http://www.ban.org/E-waste/technotrashfinalco mp.pdf.

34. Purushothaman, M., Inamdar, M. G. \& Muthunarayanan, V. (2020), Socio-economic impact of the e-waste pollution in India. Materials Today: Proceedings, https:// doi.org/10.1016/j.matpr.2020.05.242

35. Rakib, M.A. \& Ali, M. (2014). Electronic waste generation: Observational status and local concept along with environmental impact. International Journal of Scientific Research in Knowledge, 2(10), 470-479. https://doi.org/10.12983/ IJSRK-2014-P0470-0479

36. Rajput, R., Prasad, G. \& Chopra, A.K. (2009). Scenario of solid waste management in present Indian context. Caspian Journal of Environmental Science, 7(1), 45-53.

37. Ravindra, K. \& Mor, S. (2019). E-waste generation and management practices in Chandigarh, India and economic evaluation for sustainable recycling. Journal of Cleaner Production, 221, 286-294. https://doi.org/10.1016/ J.JCLEPRO.2019.02.158

38. Saoji, A. (2012). E-waste management: An emerging environmental and health issue in India. National Journal of Medical Research, 2(1), 107-110.

39. Sankhla, M.S., Kumari, M., Nandan, M., Mohril, S., Singh, 
G.P., Chaturvedi, B., \& Kumar, R. (2016). Effect of Electronic waste on Environmental \& Human health - A Review, IOSR Journal of Environmental Science, Toxicology and Food Technology, 10(9), 98-104. https://doi.or $\mathrm{g} / 10.9790 / 2402-10090198104$

40. Shamim, A., Mursheda, A.K., \& Rafiq, I. (2015). E-waste trading impact on public health and ecosystem services in developing countries. International Journal of Waste Resources, 5, 1-12. https://doi.org/10.4172/2252-5211.1000 188.

41. Shirodkar, N. \& Terkar, R. (2017). Stepped Recycling: The Solution for E-waste Management and Sustainable Manufacturing in India. Materials Today: Proceedings, 4 (8), 8911-8917. https://doi.org/10.1016/j.matpr.2017.07.2 42

42. Terazono, A., Murakami, S., Abe, N., Inanc, B., Moriguchi, Y. \& Sakai, S.I. (2006). Current status and research on E-waste issues in Asia, Journal of Material Cycles and Waste Management, 8(1), 1-12. https://doi.org/10.1007/ s10163-005-0147-0

43. Widmer, R., Krapf, H.O., Khetriwal, D.S., Schnellmann, M. \& Boni, H. (2005). Global perspectives on E-waste. Environmental Impact Assessment Review, 25(5), 436-458. https://doi.org/10.1016/j.eiar.2005.04.001

44. Zeng, X., Duan, H., Wang, F. \& Li, J. (2017). Examining environmental management of e-waste: China's experience and lessons. Renewable and Sustainable Energy Review, 72(5), 1076-1082. https://doi.org/10.1016/j.rse r.2016.10.015

45. Zhang, B., Huo, X., Xu, L., Cheng, Z., Cong, X., Lu, X. \& $\mathrm{Xu}, \mathrm{X}$. (2017). Elevated lead levels from e-waste exposure are linked to decreased olfactory memory in children. Environmental Pollution, 231, 1112-1121. https://doi.or g/10.1016/j.envpol.2017.07.015 